Discussion Paper No. 12-079

\title{
Carbon Management
}

Evidence from

Case Studies of German Firms under the EU ETS

Peter Heindl and Benjamin Lutz

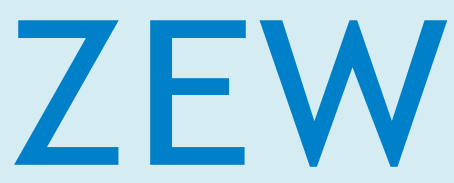

Zentrum für Europäische Wirtschaftsforschung $\mathrm{GmbH}$

Centre for European

Economic Research 
Discussion Paper No. 12-079

\section{Carbon Management}

\section{Evidence from \\ Case Studies of German Firms under the EU ETS}

Peter Heindl and Benjamin Lutz

Download this ZEW Discussion Paper from our ftp server:

http://ftp.zew.de/pub/zew-docs/dp/dp12079.pdf

Die Discussion Papers dienen einer möglichst schnellen Verbreitung von neueren Forschungsarbeiten des ZEW. Die Beiträge liegen in alleiniger Verantwortung der Autoren und stellen nicht notwendigerweise die Meinung des ZEW dar.

Discussion Papers are intended to make results of ZEW research promptly available to other economists in order to encourage discussion and suggestions for revisions. The authors are solely responsible for the contents which do not necessarily represent the opinion of the ZEW. 


\section{Non-Technical Summary}

The European Emissions Trading Scheme (EU ETS) is a key element of European climate policy. In Germany, the EU ETS currently regulates greenhouse gas emissions of about 800 companies. The regulated companies differ strongly with respect to size, production processes and the amount of emitted $\mathrm{CO}_{2}$. This discussion paper examines strategies and management practices related to compliance with the scheme's obligations. Based on structured in-depth interviews with managers, the practices of six highly different firms are illustrated and analysed against the backdrop of the results of surveys amongst regulated firms in Germany.

Management practices differ strongly between firms and are dependent on existing organisational structures, the production process, the level of emissions and the level of free allocation. Large emitters and companies of the energy sector are able to revert to existing organisational structures in order to trade emission allowances frequently. In contrast to this, small emitters of $\mathrm{CO}_{2}$ and companies of the manufacturing industry behave more passively and rely on services of intermediaries in order to minimise transaction costs. Even in large companies, monitoring, reporting and verification (MRV) is organised decentralised. The costs arising due to MRV are a burden particularly for small emitters. Large emitters develop abatement technology in-house, while small emitters buy and adopt new technologies developed by mechanical and plant engineering firms. The interviews as well as the results of the surveys show how different the institutional responses to the regulation by the EU ETS can be. The fact that regulated companies face highly different conditions leads to a situation where some firms face relatively high organisational burdens from regulation. Therefore, optimal choice and design of regulation should take heterogeneity of regulated firms into account. 


\section{Das Wichtigste in Kürze}

Das Europäische Emissionshandelssystem (EU-EHS) ist ein Kernbestandteil der Europäischen Klimapolitik. Derzeit werden allein in Deutschland die Treibhausgasemissionen von rund 800 Unternehmen durch dieses Instrument reguliert. Die regulierten Unternehmen unterscheiden sich stark hinsichtlich ihrer Größe, Produktionsprozessen und der Menge der ausgestoßenen Emissionen. Dieses Arbeitspapier untersucht die mit den Verpflichtungen des EU-EHS verbundenen Strategien und Managementpraktiken. Auf Basis von strukturierten Tiefeninterviews mit verantwortlichen Managern werden die Vorgehensweisen von sechs regulierten Unternehmen aus unterschiedlichen Bereichen beleuchtet und vor dem Hintergrund der Befragungsergebnisse des KfW/ZEW $\mathrm{CO}_{2}$ Barometers in den Jahren 2011 und 2012 analysiert.

Die Untersuchung zeigt, dass sich die angewandten Praktiken stark unterscheiden und von den bereits bestehenden Organisationstrukturen, dem Produktionsprozess, der Größe des Unternehmens, der Menge der ausgestoßenen Emissionen sowie der Höhe der freien Allokation abhängen. Große Emittenten von $\mathrm{CO}_{2}$ und Unternehmen der Energiebranche können auf vorhandene Organisationsstrukturen zurückgreifen, um regelmäßig mit Emissionszertifikaten zu handeln. Im Gegensatz dazu verhalten sich kleine Emittenten von $\mathrm{CO}_{2}$ und Industrieunternehmen deutlich passiver und sind auf die Dienstleistungen von Intermediären angewiesen, um Transaktionskosten zu minimieren. Die Überwachung, Berichterstattung und Verifizierung von $\mathrm{CO}_{2}$-Emissionen wird selbst durch große Unternehmen dezentral organisiert. Die hier entstehenden Kosten stellen ebenfalls eine Belastung für kleine Emittenten dar. Große Emittenten entwickeln eigene Vermeidungstechnologien, während sich kleine Emittenten mit neuen Technologien von Maschinen- und Anlagenherstellern eindecken. Die geführten Interviews bestätigen die Ergebnisse des $\mathrm{KfW} / \mathrm{ZEW} \mathrm{CO}_{2}$ Barometers und zeigen, wie unterschiedlich die institutionelle Anpassung an die Regulierung durch das EU-EHS ausfallen kann. Der Umstand, dass die regulierten Unternehmen völlig unterschiedlichen Voraussetzungen gegenüber stehen, führt dazu, dass die Pflichterfüllung für einen Teil der Unternehmen eine größere Herausforderung darstellt. Eine optimale Gestaltung von Treibhausgasregulierung sollte daher die Heterogenität der regulierten Unternehmen berücksichtigen. 


\title{
Carbon Management
}

\section{Evidence from Case Studies of German Firms under the EU ETS}

\author{
Peter Heindl ${ }^{*}$ \\ Centre for European Economic Research (ZEW)
}

\author{
Benjamin Lutz ${ }^{\ddagger}$ \\ Centre for European Economic Research (ZEW)
}

October 2012

\begin{abstract}
This paper examines the management practices of German firms with obligations under the EU Emissions Trading Scheme (EU ETS) based on six structured in-depth interviews with managers of firms from different industries and based on survey data. The paper sheds light on management and trading practices, abatement behaviour, and the impact of the EU ETS on long-term decisions, such as investment decisions or innovative capacity. The aim is to provide information on firm-internal management processes related to the EU ETS and to strengthen intuition for microeconomic consequences of greenhouse gas regulation in a cap-and-trade scheme. The analysis reveals that management practices in the EU ETS are mainly driven by emission levels, firm size, pre-existing management structures and production patterns. While larger emitters (about 100,000 tCO2 per year or larger) are perfectly capable to carry out all relevant tasks, smaller emitters behave more passively due to transaction costs and lower expected return of transactions. Our analysis suggests that institutional responds to regulation should be taken into account for the design of greenhouse gas regulation.
\end{abstract}

JEL-Classifications: L60; Q50; M11

Keywords: Carbon Management; Emissions Trading; EU ETS

\footnotetext{
* Centre for European Economic Research (ZEW), Department of Environmental and Resource Economics, Environmental Management, L7, 1 - D-68161 Mannheim, Germany. E-mail: heindl@zew.de

‡ Centre for European Economic Research (ZEW), Department of Environmental and Resource Economics, Environmental Management, L7, 1 - D-68161 Mannheim, Germany. E-mail: lutz@zew.de
}

We would like to thank the Sponsors' Association for Science and Practice of the Centre for European Economic Research (ZEW) and in particular Peter Bettermann for kind support and funding of the project "Carbon Management at German Companies". Such support does not necessarily imply agreement with the views expressed in this paper. 


\section{Introduction}

Since 2005, the EU emissions trading scheme (EU ETS) regulates $\mathrm{CO}_{2}$ emissions from industrial installations and power plants in the $\mathrm{EU}$ and is currently the largest mandatory domestic emissions trading scheme for greenhouse gases (GHG). Although characterised by generous free allocation of permits and a moderate constraint on overall emissions (cap), regulated firms have to comply with the schemes obligations, react on inherent risks from regulation and have to decide on long-term investments and business strategies under a highly uncertain future regulatory framework. Given real world's risks and uncertainties, the firm's responses to regulation by the EU ETS might differ from textbook predictions in the short and medium term as a number of surveys reveal (Sandoff \& Schaad 2009; Löschel, Kiehl, et al. 2010; Löschel et al. 2011; Heindl 2012; Brockmann et al. 2012; Jaraite et al. 2010; Jaraite \& Kazukauskas 2012; Rogge et al. 2011). Most importantly, cost for transacting shape firm activities in the EU ETS, where smaller emitters are usually less active in managing carbon compared to larger emitters.

The challenge of reducing greenhouse gas emissions to mitigate climate change has an impact on management practices of major emitters of greenhouse gases in many aspects. Apart of compliance with greenhouse gas regulation, such as regulation by the EU ETS, compliance with voluntary social and environmental standards and corporate social responsibility increasingly gain importance on the firm level. On the management level, economic aspects, such as costminimization, have to be balanced against mandatory regulation and voluntary environmental and social commitments. Environmental management on the firm level thus has gained importance in recent years. This requires organizational change, such as changes in management practices and processes that efficiently allow compliance with mandatory environmental regulation and voluntary environmental targets.

There is an ongoing dispute in the economic literature whether or not voluntary environmental contributions of firms will, firstly, generally be beneficial for firms, and secondly, will lead to the supply of a public good (e.g. greenhouse gas abatement) at a sufficient level (Porter \& Linde 1995; Palmer et al. 1995). There is, however, support for the thesis that firms might gain from being "green" if there is strategic competition and firms can successfully differentiate products when there is demand for "green products" (André et al. 2009). This in turn will limit the benefits of voluntary environmental contributions to firms that are able to successfully differentiate their products or the public recognition of their corporate identity and culture.

This paper contributes to the literature on mandatory greenhouse gas regulation on the firm level in synthesis with voluntary environmental efforts of firms by examining the management practices of six firms in the EU ETS as well as management practices related to greenhouse gas reduction on a voluntary basis. The paper summarises the results of six semi-structured topical interviews of managers responsible for emissions trading in German companies. It provides insights on firm-internal management processes related to the EU ETS to strengthen for the understanding of microeconomic consequences of GHG regulation. The interviews will be discussed in the light of general economic theory and institutional economics in a broader sense as suggested by Solomon (1999).

In recent years, a considerable body of literature on firm responses to regulation by the EU ETS evolved. Since there are only few datasets available that allow for broader empirical examination, 
many contributions are based on relatively small datasets, numerical simulations or case-studies. While numerous ex-ante studies predicted partly severe consequences of the EU ETS for the competitiveness of branches like cement, steel, oil-refineries or aluminium, and as a consequence partly high rates of carbon leakage, early ex-post studies were not able to observe any impact of the EU ETS on the competitiveness of the European industry (Ellerman et al. 2010). Also for the case of Germany, early ex-post studies found no significant impact of the EU ETS on competitiveness (Anger \& Oberndorfer 2008). However, with increasing stringency of regulation, a tighter Europe-wide emissions constraint and rising prices in the long-run, consequences for competitiveness are likely to occur and the EU ETS will play a more prominent role in determining firm strategies and behaviour under regulation.

Firm responses to the EU ETS have raised the interest of various academic disciplines from business administration (V. Hoffmann 2007; Egenhofer 2007; Okereke 2007) to engineering (Kautto et al., 2011; Radgen et al., 2011; Zhang \& Wei, 2010) and even sociology (Engels 2009). From a strictly economic point of view, three aspects might be of interest: practices in permit trading, abatement activities and decisions with regard to investment in abatement technologies and innovation. Trading activities and strategies might be highly influenced by short-term conditions, such as price expectations and availability of free allocation. Abatement and investment decisions, on the other hand, might be influenced by condition in the medium-term, such as overall expectations on future regulation. The problem of investment leakage, for instance, has gained increasing interest in recent years (Bednar-Friedl et al. 2012).

An early study carried out in 2006 on 114 Swedish firms found that abatement measures are considered partly without "close attention" to the permit price, indicating a lack of institutional capability of firms to cope with the EU ETS (Sandoff \& Schaad 2009). It was also pointed out that firm responses might depend crucially on the firm's characteristics, such as emissions levels and employed technology (Matisoff 2010). For the German case it was reported that incentives for innovation that stem from the EU ETS are moderate (Rogge et al. 2011). A number of other factors ("context factors") apart of the EU ETS seem to be more important determinants for decisions on innovation according to Rogge et al. (2011). The authors further find that the impact of the EU ETS "[...] varies significantly across technologies, firms, and innovation dimensions and is most pronounced for RD\&D on carbon capture technologies and organizational changes". Surveys amongst German firms under the EU ETS from 2010 and 2011 showed that firm activities in the EU ETS are highly dependent on the total emissions of a firm. The more a firm emits the more active and informed it is on average. The results also suggest that larger emitters set up much more sophisticated internal schemes to manage the EU ETS compared to small emitters (Löschel, Kiehl, et al. 2010; Löschel et al. 2011; Brockmann et al. 2012; Löschel, Heindl, et al. 2010). Costly transactions, e.g. costs for gathering information, costs for arranging permit trades or costs for analysing options for GHG abatement might explain the observed patterns (Heindl 2012; Jaraite et al. 2010; Jaraite \& Kazukauskas 2012). To examine the motivation of firms for spending effort on carbon management more closely, special attention was paid to the hypothesis of costly transactions as a driving force for a firm's activities in the EU ETS during the interviews.

The interviews took place in August and September 2011 and were carried out by two researchers in the form of semi-standardised topical interviews (Arthur \& Nazroo, 2003; Rubin \& Rubin, 2004). All interviews except for one were recorded to ensure that all relevant aspect could be 
summarised later on and no details were lost. The interview summaries, presented in section 2, were double checked with the interviewed persons. All interviews were carried out based on a questionnaire closely orientated on surveys carried out in 2010 and 2011 to allow for comparison (Löschel, Kiehl, et al. 2010; Löschel et al. 2011). The interviewed persons were invited to answer the questions freely so that additional detailed aspects of the firm's management processes could be captured in more detail than in a survey. Topics addressed during the interview include general information on the firm, abatement activities, activities in permit trading, investment strategies and competitiveness issues. The detailed questionnaire can be found in the appendix.

The paper organises as follows. In section 2, the detailed summaries of all six interviews are presented. Section 3 discusses the results and compares them to the findings of the surveys carried out in 2010 and 2011. Section 4 concludes.

\section{Description of Cases}

\subsection{Case 1: An International Active Producer of Intermediate Goods}

The interview was conducted with two persons responsible for energy and carbon trading. The corporate group has 33,000 employees worldwide and generates a volume of sales of EUR 5 billion per annum. It produces a large variety of intermediate and final goods, inter alia for the automobile industry. In Germany, the company has 25 production sites. In addition, the company runs production sites in countries such as Japan, the USA, Mexico, China and India. At other European production sites, only combustion installations with less than 20MW thermal power are installed and are not covered under the EU ETS. The company is exposed to a difficult competitive environment due to innumerable competitors located all over the world. The energy and carbon trading desk belongs to a subsidiary supplying several services to the legally independent branches of the company located in the same area. The subsidiary runs its own heating and power plant (highly efficient trigeneration, supplying combined heat, power and cooling). The heating and power plant was completely renewed in 2005. It was renewed primarily as a result of a German law from 2002 for the promotion of combined heat and power generation and in anticipation of the EU ETS. The technical life cycle is expected to be about 30 to 40 years. The installed electric and thermal capacity amounts to $33 \mathrm{MW}$ (23MW in use) and $155 \mathrm{MW}$ (60MW in use), respectively. The historical emissions of the installation were close to $70.000 \mathrm{tCO}_{2}$ in 2008, slightly below $65.000 \mathrm{tCO}_{2}$ in 2009 and about $68.000 \mathrm{tCO}_{2}$ in 2010. The free annual allocation for Phase II of the EU ETS (2008-2012) is set at 141.000 tCO $_{2}$. Hence, the plant receives a relatively high amount of over-allocation. As a consequence, the carbon management unit focuses strongly on an efficient use of the received over-allocation. The profit center is exposed to other expenditures from environmental regulation too. Most prominently, the EEG redistribution mechanism of the German regulation for renewable energy promotion generates additional expenditures that amount to roughly EUR 2 million per annum. Currently, the subsidiary profits from the generous free allocation in Phase II, generating surpluses of roughly EUR 1 million per annum. Due to the changed allocation rules starting from 2013 onwards, the subsidiary expects to have additional expenditures for permit purchases of slightly below EUR 1 million per annum. The manager estimates that the installation will receive approximately 30,000 permits via free allocation in 2013, gradually dropping to approximately 
10,000 permits until 2020. The costs from permit purchases are expected to be roughly EUR 1 million per annum in the end of Phase III (2013-2020). According to the manager, this does not lead to direct or immediate carbon leakage but contributes to a reduction of expected future earnings and enhances the risk of carbon leakage when production facilities will be renewed. When a new production line is set up, costs are compared across different sites. In this case, the German site under EU ETS regulation often is less cost efficient mostly because of rising energy prices including carbon prices.

The company permanently observes the developments on the carbon markets. Prices of derivatives are used as a proxy for future price development. This procedure allows the company to develop its own price expectations, contrasted by peer-to-peer contacts to other managers of facilities regulated under the EU ETS and by information provided by lobby groups and intermediaries. Price volatility on the carbon markets are perceived as highly negative, according to the manager. For the financial evaluation of investments, conservative price estimates are used in the sense of a precautionary principle and long-term planning, which is seen as part of the organisational culture in the company.

The company becomes active in trading six times per year on average. Trading activities are clearly driven by the amount of surplus allowances. Energy (gas and electric power) trading and carbon permit trading are located in the same department and conducted by the same person. Trades are proposed by the managers of the facilities but have to be permitted by the management board of the subsidiary. Since selling of surplus permits contributes considerably to the performance of the subsidiary, the managers have well defined incentives to optimise permit sales. However, the manager points out that "speculation" is clearly forbidden by the internal rules of the company. Neither futures nor options are traded because the company rates the usage of derivatives as "speculation". Usually trading European Union Allowances (EUAs), the company recently conducted a EUA-Certified Emission Reduction (CER) swap for the first time. The main reason for that action is the dramatic drop of EUA prices in June and July 2011. The company carries out all transactions in carbon and energy trading via intermediaries. With regard to technical aspects, the manager states that they are informed about the newest technology. The installation of more efficient machinery, such as installations for cooling, are permanently considered in the light of many variables including the price for $\mathrm{CO}_{2}$ in an assessment of profitability of investing in new installations. While the measurement, reporting and verification (MRV) of emissions is necessary, the observation of the market and the management of permits sales are seen as an additional task that comes along with great effort for the two responsible managers. The effort is spent approximately half on MRV and half on trading. The company uses the services of intermediaries for verification of emissions (obligatory), for trading of allowances and for legal support and advice in the event of application for free allocation in the run-up to phase two and three of the EU ETS.

The company has general guiding principles for environmental performance. These principles do not influence the management of emissions trading in detail. In the carbon management, only technical employees are active, no employees with a business or commercial education. Inside the company there is a general internal suggestion scheme which partly offers bonuses for efficiency rising suggestions. The suggestion scheme contributes to general energy efficiency, but rarely 
alters the overall production and emissions level of the power plant. The company has a certified (ISO14001) environmental management scheme (EMS). However, the EMS has a minor impact on the management of the EU ETS inside the company, according to the manager. Due to the already achieved high level of efficiency, innovation with regard to the carbon emitting installation plays just a little role for the company. Searching for new or alternative technology for the combustion installation occurs permanently by the two-person carbon management team.

\subsection{Case 2: A Large Coal-Fired Power Plant}

The interview was conducted with two responsible persons for the strategic and technical management of emissions trading. The company has about 600 employees and generates a volume of sales of EUR 450 million per annum. The company is a supplier of power and heat operating five large steam coal fired cogeneration plants. Optimised for power supply, the installations produce more than 6 billion kilowatt-hours of power per annum and supplies district heat to about 110,000 households. Verified emissions varied between 6.5 and 7.0 million $\mathrm{tCO}_{2}$ in recent years. Since the company received free allocation of roughly 6.0 million permits, it was short of allowances. In 2013, the company expects to receive less than $10 \%$ of current (phase two) allocation for free.

The five coal plants have an overall gross capacity of about $1700 \mathrm{MW}$. Three installations have an electrical efficiency of $40 \%$ to $42 \%$. The two remaining installations are designed for flexible reaction on power demand and show a lower efficiency degree. These two installations have a run-up time ranging from 1.5 to 4 hours dependent on the state of the installation. A new coal fired power plant, currently under construction, will be connected to the grid within the next years. The new plant is expected to have an efficiency degree of $46.4 \%$. Retrofitting of existing plants takes place and actually contributes to the reduction of $\mathrm{CO}_{2}$ intensity per unit output. Such activities are mostly driven by technical considerations. $\mathrm{CO}_{2}$ mitigation thus mostly occurs as a side effect. Moreover, the company aims to further enlarge the district heating network in the future.

The company has evaluated mitigation options and considered fuel switch (to steam coal of higher quality which yields lower $\mathrm{CO}_{2}$ emissions) ${ }^{1}$. However, such a fuel switch is economically not feasible under current market conditions and the current price range for European Emissions Allowances. For the future, Carbon Capture and Sequestration (CCS) is in principle considered as an option to reduce $\mathrm{CO}_{2}$ emissions. The plant that is currently under construction will be "CCS ready", meaning that retrofitting of capture facilities will be in principle possible. For CCS to be realised, the most important problems are located in the infrastructure for $\mathrm{CO}_{2}$ transportation (e.g. pipelines) to possible storage sites and in the loss of efficiency of combustion plants when $\mathrm{CO}_{2}$ is captured (minus 10 to 15 percentage points, according to the technical officer). However, the company invests in a business-to-university cooperation for research and development of carbonate looping ${ }^{2}$ technologies. It provides mostly human resources and steam coal to a

\footnotetext{
${ }^{1}$ The approximate range of $\mathrm{CO}_{2}$ emissions from black coal combustions ranges from 92 to 98 ton $\mathrm{CO}_{2}$ emissions per terajoule, according to the technical officers statement.

2 Carbonate looping is a technical process of carbon capturing that requires relatively low energy input and is associated with a relatively low loss of electrical efficiency. In general, carbonate looping is a promising technology for retrofitting of existing plants.
} 
research project with a larger range of supporting partners. The value of provided resources for the research project amounts to roughly EUR 100,000 for the first stage of the project. More investments in later stages of the research project are expected by the managers. The company also invests in research and development of new technology (process innovation) that allows the transportation of steam with a higher temperature and increases the electrical efficiency of existing installations and hence leads to a reduction of $\mathrm{CO}_{2}$ emissions. The $\mathrm{R} \& \mathrm{D}$ investment is carried out in a consortium of different companies and is supported by the EU.

The company faces competition by alternative forms of power generation, such as natural gas, renewables or by decentralised heating solutions. The effective amount of produced power is indirectly determined by market prices. The company does not sell power directly to the market. Instead, several larger holding companies order individual amounts of power and sell them to the market. The amount of ordered power and heat is subject to seasonal effects and dependent on daytime and the day. Seasonal demand factors and the supply of power at energy exchanges jointly determine the effective output of the company. The holding companies evaluate and rank the coal-fired power plant based on costs and prices on energy exchanges and decide individually which amount of power and heat is demanded.

While most inputs for production are purchased by the company, trading of emissions allowances is conducted by the holding companies. The holding companies supply the emissions allowances needed for the production of their ordered amount of power directly to the company so that no market transactions of emissions permits have to be conducted by the responsible managers inside the company. Hence, the price for $\mathrm{CO}_{2}$ emissions is included in the calculations of the holding companies when selling power at energy exchanges, influencing their orders of power generated by black coal made to the company. The price for $\mathrm{CO}_{2}$ allowances determines the company's production and business perspectives jointly with other factors, such as commodity prices and general domestic energy policy. While the phase-out of nuclear energy production is expected to support power production from steam coal in the long run, the promotion of renewables requires increasing flexibility in power supply and does increase the existing seasonal effects.

Within the company, carbon management is restricted to the measurement and reporting of annual emissions. As mentioned before, trading is scheduled by the holding companies. For verification of emissions a third-party verifier is employed. No other external services related to emissions trading are demanded by the company. The costs for MRV are considered as sizeable, but affordable for the company. This is due to the relative large amount of emissions, according to the managers.

While the managers assess the regular transaction costs of emissions trading for their company as acceptable, they point out that the application for free allocation for Phase III is associated with high effort and comes along with relatively high costs. In the process of application for free allowances additional third-party assistance by law-firms are needed to comply with the application rules. Moreover, application rules are assessed as highly complex. Less complex rules for application are regarded as one of the most important options for making emissions trading easier to handle and more feasible for regulated companies. 
The company has a certified (ISO14001) environmental management scheme. Holding companies do not expect the company to have an EMS. The scheme is not directly related to emissions trading, ${ }^{3}$ but generates positive effects in general. This includes a positive signaling towards the public society and public authorities. Hence, the EMS is seen as beneficial in general. Overall, the motivation for the introduction of an EMS was to increase the efficiency of internal and existing processes related to environmental issues and to benefit from the positive image related to an EMS.

With regard to uncertainty, short-run volatility of prices seems not to be a central issue. In contrast, uncertainty related to long term domestic energy policy and long term European climate policy is of great importance for the managers. From their personal experience, the managers express the view that emissions trading is relatively complex and demanding in terms of organisational effort. A tax on $\mathrm{CO}_{2}$ emissions is expected to be accompanied by less overall transactions costs and less organisational effort.

\subsection{Case 3: A Company from the Food Industry}

The interview was conducted with one responsible manager for carbon trading. The company has a central trading department for commodities. The company belongs to the food industry, operates in a highly regulated market and is not allowed to supply their main product outside Europe. The European and German market share is approximately $25 \%$ and $40 \%$, respectively. Due to regional available inputs and the regulated market, the company faces moderate competition. Most importantly, there is only little competition from outside Europe. The company runs production sites in Germany, France, Belgium, Poland, Austria, Czech Republic and Moldova. The product that is produced in EU ETS regulated installations accounts for about $55 \%$ of the sales volume of the company. The overall annual sales volume was about EUR 6.2 billion in 2010, while earnings amounted to about EUR 500 million. The company employs about 17,700 employees, mostly in Europe. In Germany, the company runs 22 installations regulated under the EU ETS. Since the production process requires steam, combustion installations and installations for the production of lime are operated. The combustion installations are heat led cogeneration plants with efficiency of 90 to $95 \%$. Dependent on the availability of fuel and the location of plants, different fossil fuels, such as heavy fuel oil, gas, brown coal or black coal are used for combustion. Also coke and anthracite are used for combustion in lime production. Electric power is a byproduct in steam production. An outsourcing of existing installations, e.g. external purchasing of steam, is theoretically possible but comes along with costs and risks and, hence, was not yet realised. In Phase II of the EU ETS the company receives an over-allocation of permits. In Phase III the company expects to be short of allowances. Currently, the relevant benchmarks are not known by the company, leading to uncertainty about future allocation. On average, verified emissions for the years 2008 to 2010 amount to 750,000 tCO $\mathrm{CO}_{2}$ per annum. Free allocation in Phase II amounts to roughly $900.000 \mathrm{tCO}_{2}$ per annum, resulting in a net long position of $150,000 \mathrm{tCO}_{2}$ per annum on average. For 2013, the interviewed manager expects that the company will receive approximately $50 \%$ of the free allocation it received during the Phase II.

\footnotetext{
3 The process of emissions reporting is described in the EMS. Since there are relatively strict rules regarding the process of emissions measurement, reporting and verification, the EMS might have no direct impact on the companies reporting activities.
} 
This would lead to a short position of about 300,000 permits per year. The company's products belong to the sectors and subsectors which are deemed to be exposed to a significant risk of carbon leakage ("carbon leakage list").

Currently, the long position determines the trading strategy of the company. Trading is organised via intermediaries (different banks). The company does not trade directly at exchanges. Because of the post 2012 uncertainty regarding Clean Development Mechanism (CDM) and Joint Implementation (JI), the company currently does not purchase CERs or Emission Reduction Units (ERUs) for Phase III of the EU ETS. In Phase II, the company aims to use as much CER and ERU permits for compliance as possible. When purchasing CERs or ERUs, swaps with EUAs were used. In general, speculation is not allowed by the internal rules of the company. Swaps are not considered as speculation. However, neither futures nor options for carbon permits are traded. Trading activities occur frequently. In 2010, the company traded about 20 times. The decision for permit purchases is made in meetings with the responsible member of the executive board on a regular basis. There is no trading without an explicit order of the responsible member of the executive board. Purchases are usually split into several tranches for risk diversification. The company currently does not sell, but banks permits for the third trading period. To be informed about the market, a daily report is produced including the price for $\mathrm{CO}_{2}$ amongst other commodity prices. Additional information is gathered by direct contact to banks before each strategic meeting.

Concerning production or investment decisions, prices for $\mathrm{CO}_{2}$ are of relatively low importance at the current price level. For investment decisions, a fixed price for $\mathrm{CO}_{2}$ is used for calculation. Since 2005, the company has not implemented $\mathrm{CO}_{2}$ abatement measures. The existing combustion installations are maintained annually to ensure operability and efficiency. As the interviewed manager states, the production process cannot be changed so that existing combustion installations could be replaced. Some production sites allow for fuel switch (gas to oil/oil to gas). The fuel switch decision currently depends on the oil/gas price ratio rather than on the price for $\mathrm{CO}_{2}$ emissions. As a consequence, gas is currently used for combustion. The remaining combustion facilities do not allow any fuel switch. Also a fuel switch to higher efficient coal is not considered.

The combustion installations and the energy trading department are not organised as profit centres. The combustion installations are organised as part of each single production site and are maintained by local responsible technical managers. The central service for energy and carbon trading operates as part of the central management and aims to optimise commodity contracts. However, combustion installations and the central service do not compete with alternative power suppliers. This is mainly because of the need for steam in production, which cannot be easily purchased on the market. The company did not evaluate abatement options and costs explicitly because no economically efficient abatement options are expected to be present. For Phase III, considerable costs for additional permit purchases are expected for the whole company. For carbon prices to play a more prominent role in investment decisions, prices must be relatively high (approx. EUR 30 to 40), according to the interviewed manager. Hence, the company is currently not willing to invest in carbon dioxide abatement. Reasons for that are, inter alia, the uncertainty about future greenhouse gas regulation in Europe and uncertainty about future regulation of the key market of the company. 
Concerning carbon leakage, the company seems to be mildly concerned. The company runs one installation in Moldova. However, the amount of produced goods is relatively low compared to remaining production sites regulated under the EU ETS. The optimal spatial allocation of production is highly driven by transportation costs for inputs as well as the final goods. As a consequence, production is located where inputs are available, following the logic of a Launhardt Weber problem. Prices for carbon dioxide emissions seem to be of relatively low importance compared to transportation costs. In contrast, the company contemplates to generate offset permits in its plant in Moldavia via the generation of renewable energy. The company expects that the generation of 10,000 to 15,000 offset permits per annum would be possible. However, the option for offset generation in Moldova did not influence the location decision of the company but is seen as a positive side effect.

With regard to carbon management in general, trading is organised in a centralised manner with one responsible person for permit trading. In contrast, compliance is organised decentralised. In each plant there is a person who is responsible for MRV. In the company, sustainability is in general an important topic, but is not directly related to the companies $\mathrm{CO}_{2}$ emissions from EU ETS regulated installations. However, electric power that is purchased externally by the company stems from non-fossil sources. Overall, the company employs one trader only partly concerned with $\mathrm{CO}_{2}$ trading (about 20 workdays per annum). A central environmental manager is responsible for $\mathrm{CO}_{2}$ reporting and the contact to public authorities and politicians. For the whole central management, about one to one and a half full time position is needed for the management of the EU ETS. In addition to that, one responsible person for MRV is located in each plant. At each plant, about one quarter of a full-time position is needed for compliance. These persons are responsible for the correctness of emission reports. The company has no suggestion scheme for employees.

For the application for free allocation in Phase III, external services, such as legal and technical advice are used. The interviewed manager stated that as long as there is uncertainty about the future trading phase, the company takes a wait and see position. While currently banking is the dominant trading strategy in the company, the strategy will be updated when the actual free allocation for Phase III is known. General uncertainty regarding climate policy and energy policy negatively influences the company's situation.

\subsection{Case 4: A Company Producing Inputs for the Construction Sector}

The interview was conducted with the company's head of European regulatory affairs. Internationally active in more than 40 countries, the company produces inputs for the construction sector. The company employs about 55.000 persons worldwide and had a sales volume of more than EUR 11 billion in 2010. The market in which the company is active consists of few large competitors and a large number of small firms. In Europe, about 10 companies cover about $75 \%$ of the market share. On the global level, China is one of the most important markets. New production capacities are established almost entirely outside Europe, according to the interviewed manager. As a consequence, competition from outside Europe is growing. Chinese producers grow fast and become increasingly important players on a global level. Transportation costs for the good, e.g. from China to Europe are currently about one 
quarter of the price of the good on European markets. The produced good is highly energy and capital-intensive. The company runs 43 installations covered under the EU ETS in Europe. In 2009 and 2010 the company received a significant amount of over-allocation. Before the start of the second phase of the EU ETS, the company expected to be short of free allocation. According to the manager, the significant amount of over allocation stems from the economic downturn of the years 2008 and 2009. The company sold a large amount of permits to the market in 2009 and 2010. For 2013, the company does not expect to be short of freely allocated allowances in continuation of the effects of the crisis.

The facilities operated by the company under the EU ETS jointly emit about $20 \mathrm{MtCO}_{2}$ per annum. Because of the energy-intensive nature of the production process, the company explicitly aims to reduce energy consumption and to reduce $\mathrm{CO}_{2}$ emissions. The company also has internal goals for $\mathrm{CO}_{2}$ emissions reductions and achieved a significant reduction of $\mathrm{CO}_{2}$ emissions per unit of produced good over the last twenty years.

$\mathrm{CO}_{2}$ emissions occur in two different ways in the production process of the company. 60 to $70 \%$ of emissions occur as process emissions. The remaining 30 to $40 \%$ stem from combustion installations. In terms of $\mathrm{CO}_{2}$ abatement, the options to reduce process emissions are highly limited because of the complexity of the production process. The company is actually investigating options for process emissions reductions and has examined options for $\mathrm{CO}_{2}$ abatement for all plants. The combustion processes offer two options for emissions reductions. Firstly, emissions reductions from increased energy efficiency of the combustion installations and secondly, the option of switching fuels. The switch from coal to gas is not applied because of high gas prices. The company partly co-fires waste materials (appr. $15 \%$ of used fuels in 2010) and biomass (appr. $5 \%$ of used fuel in $2010^{4}$ ) to achieve emissions reductions and costs savings. The average efficiency of the existing combustion installations in the company amounts to roughly $70 \%$. The efficiency cannot be easily increased because of the special production. For instance, the use of waste heat for purposes, such as power generation or heating is rarely applied in Europe. Such measures would require significant investments. In newly build plants, e.g. in China or Turkey, installations for waste heat use are included. However, retrofitting of existing plants in Europe seems not to be an economically option given the current regulatory and economic situation. The company also invests in research and development for carbon capture and storage facilities.

According to the interviewed manager, currently the price for $\mathrm{CO}_{2}$ has a negligible impact on current investment decisions at existing plants. While in the long run, prices for $\mathrm{CO}_{2}$ emissions are considered as a potential important driver for production costs, current investments that could reduce $\mathrm{CO}_{2}$ emissions would never be paid-off by $\mathrm{CO}_{2}$. In contrast, the reduction of energy costs and the increase of general cost efficiency in production are the main drivers for investments. The interviewed manager points out that in the course of unpredictable general climate policy in Europe such investments cannot be carried out based on a strong price signal that stems from the EU ETS. As a consequence, uncertainty about future climate policy strongly hampers the implementation of significant additional investments to reduce $\mathrm{CO}_{2}$ emissions in practice. The interviewed manager further points out that uncertainty is not only limited to the

\footnotetext{
${ }^{4}$ Volumes of co-fired materials are average volumes on the group-level. Co-firing in Europe occurs to a much higher extent, according to the interviewed manager.
} 
farer future. As an example, the uncertain situation regarding the free allocation in the EU ETS from 2013 onwards is named.

Apart from general uncertainty about future European climate policy, the interviewed manager emphasises the importance of global approaches to achieve sustainable greenhouse gas reductions to prevent carbon leakage and to protect the European industry. The interviewed manager says that uncertainty regarding European climate policy and lower requirements outside Europe lead to the current situation in which the company does not invest in new plants in Europe. As a consequence, investment leakage is assessed as a more important issue than carbon leakage in the form of a reallocation of production. According to the manager, this implies that highly efficient new plants are currently built in China and elsewhere outside Europe also leading to a technology transfer to the respective regions. Consequently, investment leakage has an indirect impact on domestic facility suppliers.

Regarding commodity and energy trading, the company has a separate trading department that engages in the market every day. This department trades directly on exchanges and over the counter. Although carbon trading is centralised, the different facilities are treated separately. This implies that short-long positions are not cleared inside the company. Each plant is responsible for its own emissions and has to pay for additionally purchased permits or receive the revenue of sold excess permits. This trading strategy was decided by the management board of the company. The company's rules forbid trading motivated by speculation. Neither futures nor options are traded by the company. CERs and ERUs are traded and used for compliance, including swaps of EUAs against CERs. The company aims to use as much CERs or ERUs as allowed by the member states regulation. In addition, the company carries out projects for CER and ERU generation in the primary market. To analyse the markets, the company carries out own market research and makes price forecasts. Frequent reports about carbon issues are made to the responsible members of the management boards. One member of the management board is responsible for trading in general and also for carbon trading. Irregular meetings with responsible members of the board are scheduled when necessary. The management processes are designed to allow a quick reaction on the situation on the markets.

The general carbon management structure inside the company is very advanced. The central trading division assures appropriate and quick reaction on changing conditions in the market. The company seems to be very well informed about the market situation and ongoing changes in general climate policy. Installation specific trading sends individual incentives to the managers of each plant to optimally control for $\mathrm{CO}_{2}$ emissions. Furthermore, employees are included in the achievement of energy savings via a suggestion scheme. Most facilities have environmental management schemes, such as ISO14001. All installations in Europe are covered by an environmental management scheme. The company aims to have environmental management schemes installed in all installations until 2020. The transaction costs for organising carbon management are assessed as "extremely high" by the responsible manager. In each installation and in each country there are $\mathrm{CO}_{2}$-coordinators. Also costs for application for Phase III free allocation are assessed as high. The company went to court in the past to sue over the received free allocation and expects to have similar legal costs in the future. The highest share of transaction costs occur for MRV. In each plant about a half-time equivalent is concerned with 
$\mathrm{CO}_{2}$ issues. For MRV the needed manpower sums up to about 30 full time employees for the whole company.

\subsection{Case 5: An Internationally Active Producer of Machinery}

The interview was conducted with one manager responsible for carbon management and the purchase of energy, services and other goods. As an engineer, he has a strong technical background and is now working as head of the department in a mainly commercial position. The company develops and constructs technical high-end equipment and machinery and is active in a global market. The company generated an overall sales volume of EUR 2.6 billion in 2010 . Production sites are mainly located in central Europe, except one factory that was built in China in order to supply the Chinese market. The company is active on a global market. The company has one installation that is regulated by the EU ETS. The bi-fueled heating plant that is located in Germany at the company's largest production site has an installed capacity of about 32 MW and provides the factory buildings with heat. The plant was built in the early 1990s and has been upgraded regularly motivated by technical and energy efficiency issues. Depending on the price spread between heating oil and natural gas, the installation is mainly run with natural gas. Due to the heating purposes of the plant, the emissions highly depend on the weather conditions. On average, the plant emits 6,700 $\mathrm{tCO}_{2}$ per annum. Free allocation in Phase III amounts to roughly $5,700 \mathrm{tCO}_{2}$, leading to an annual net short position of about $1,000 \mathrm{tCO}_{2}$ on average. The company assessed the possibility of outsourcing the existing plant, but the costs and risks outweigh the benefits by far. Instead, the company plans to install two cogeneration units with the capacity of $1 \mathrm{MW}$ each, in order to produce electricity and to increase the efficiency of the installation. The manager stated that the company is highly interested in keeping the installed technology as efficient as possible due to fuel saving considerations and general economic concerns. However, the company did not evaluate technological abatement options and costs explicitly because no economically efficient abatement options are expected to be present.

Concerning the supply of natural gas and electricity, the general purchasing unit only enters into long-term contracts with the energy supply companies. The company does not operate a trading desk responsible for raw materials and energy. Further, the company is not engaged regularly in the carbon market: It was engaged once during Phase I and it has not actively traded EUAs since the start of Phase II. Laid down by the company management, the trading strategy is to buy EUAs only when they are needed. For annual compliance, the company borrows permits from next year's free allocation and aims to clear its position at the end of the trading phase. As far as the current situation is concerned, the company has only to buy the needed amount of certificates of about 5000 EUAs in the end of Phase II. Due to the small amount of EUAs and therefore the small value at stake, the trading is totally independent from the price development on the EUA market. The interviewed manager assesses the current EUA price development once a week, but neither price forecasts nor market research is conducted by the company in question. While the company does not buy any services concerning market information or legal support, only the company's principal bank is involved in processing the EUA purchases Furthermore, the company does not trade derivatives and has not considered options of using ERUs and CERs for compliance up to now because of information costs and risks. Due to regulatory uncertainty, the manager has not made estimates for the free allocation in Phase III yet. 
The interviewed manager is in charge of the MRV process and the application for free allocation in Phase III. He also supervises the purchase of the needed EUAs carried out by the treasury department. The facility management provides the interviewed manager with the fuel and emission data of the installation. Overall, the manager judges the whole labour costs that stem from carbon trading and management as negligible. The needed data is recorded and collected anyway, while the internal efforts of the MRV and trading processes only take a few working days per year (manager: one week; other employees: altogether about 20 days). The biggest share of transaction costs evolves during the reporting and verification process: The annual costs of the verifying service provider amount to EUR 2,200 on average not including an additional EUR 2,200 for external services during the application for free allowances occurring once per trading phase.

The firm's customers have high requirements concerning sustainability. Therefore, the company has strong incentives to reduce emissions: It has a general environmental long-term objective of producing $\mathrm{CO}_{2}$ neutral. This goal comprises all areas in the company, such as production, transportation and the company's car fleet. For example, some production sites are driven exclusively by power purchased from an eco-electricity supplier. The company has an employee suggestion system that rewards profitable and reasonable suggestions in all areas including environmental improvements in the firm's processes. Furthermore, the company has a certified environmental management scheme (ISO 14001). An expansion of the environmental management scheme is planned. However, the EMS and the general emission reduction target have a minor impact on the management of the EU ETS inside the company according to the manager.

The manager judges the regulatory uncertainty as suboptimal, but highlights mainly problems on the operative level (e.g. IT problems). He also complains about inequalities in the EU ETS: Small emitters are treated like large emitters in terms of reporting and verification duties. He demands reliefs for small emitters. In this context, he points out that the verifying service providers are the bottleneck in the MRV process and demands an alteration of the time schedule: The reporting and verification period of small emitters should be different from that of large emitters. That might ease pressure on verifying service providers that are bound by strict time schedules.

\subsection{Case 6: A Medium-Sized Utility Company}

The interview was conducted with a manager responsible for energy and carbon trading of a medium-sized energy supplier. While the overall number of employees amounts to about 6,000 , the group generated an overall sales volume of EUR 3.4 billion in 2009/2010. As shareholder of several renewable and conventional power plants as well as regional utilities, the group supplies private households and companies with electricity, gas and heat. Due to the liberalisation of the gas and electricity market, the group faces strong competition at generation and end-customer level. Sustainability is one of the group's key objectives: Climate protection and preservation of resources belong to the general objectives. The group plans to increase the share of renewables in power generation up to $30 \% 2020$. Furthermore, the group is engaged in an electro mobility project. The targeted increase in renewable energy generation is mainly driven by demand factors. For such strategic decisions, the price on $\mathrm{CO}_{2}$ is of minor importance. The companies $\mathrm{CO}_{2}$ 
emissions amount to roughly 4 million $\mathrm{tCO}_{2}$ in 2010. The company receives about 2.5 million $\mathrm{tCO}_{2}$ free allocation in phase two, and hence is short of allowances. Overall, the company owns or holds shares on several installations regulated under the EU ETS.

The interviewed manager is head of the department 'Front-Office'. The department belongs to a subsidiary of the energy supply company that is responsible for electricity, commodity and carbon trading as well as the relevant market research. Further key missions are portfolio management (e.g. optimisation of operational planning on the plant level) and the group-wide risk management. Services for external customers are among others the purchase and sale of several gas and electricity products. The trading subsidiary organises the carbon trading including hedging for the producing plants. The department orders certain amounts of electricity and heat at several plants, depending on the current market situation. The optimisation is made on the day ahead and intraday market. For the respective carbon content of ordered energy, the department purchases emissions allowances and delivers them to the plants. Compliance with the EU ETS is in general organised at plant level and not at the central trading department. The carbon price influences the group directly at several levels: The operational planning on the plant level is based on spread management. Here, based on the merit order theory, the carbon price is beside the electricity price, exchange rates and fuel costs one decisive factor for plant utilisation. In this way, the operation of the plants is planned on a day-ahead basis. In the long run, the carbon price influences investment decisions and consequently the generation portfolio. Furthermore, as a service, the trading subsidiary offers to organise purchase and sale of EUAs, CERs and ERUs.

The company trades EUAs, CERs as well as ERUs. The volume of traded EUA futures is much higher than trading volume of spot EUAs. Futures are primarily traded via exchanges (ICE), but also off-market (OTC, financial intermediaries, bilateral, auctions). The company aims to use as much CERs and ERUs for compliance as possible. Trading activities occur frequently.

Mitigation options are analysed at the plant level. Possible projects are discussed with other shareholders of the power plant companies in question. The restructuring of the generation portfolio that foresees high investments in renewables has severe consequences for the conventional power plants. A higher flexibility in operational planning is needed. This affects the technological but also the organisational side.

In the trading department 5-6 employees are engaged in emissions trading and market research. The total time spent on the topic amounts to 2-3 full-time positions. In the whole group about 15-20 employees are concerned with emissions trading, including risk management, market research and policy issues. Besides personnel costs, also costs for the access to exchanges and the trades evolve. These costs are negligible in comparison to the capital costs of collateral that is necessary in the context of margining. In general, the most important part of transaction costs are labour costs. Since the company is not directly engaged in MRV activities, no such costs occur.

According to the interviewed manager, regulatory uncertainty has consequences for the pricing at the EUA market. The market is highly sensitive with respect to policy announcements. Currently, the debt crises, the possible high amount of allowances set aside and the energy efficiency directive are giving strong impulses to the market. The interviewee states that a central auctioning platform would be preferable. The current situation of several exchanges auctioning EUAs leads to rising transaction costs (e.g. due to organisational effort), according to the manager. 
Furthermore, he considered possible negative consequences for pricing due to the fact that some auctioning platforms have only few participants.

\section{Summary and Comparison of Cases}

\subsection{Carbon Management in German Companies}

Basic carbon management practices of German companies regulated by the EU ETS are described in two surveys carried out in 2010 and 2011 (Löschel et al., 2011; Löschel et al., 2010a; Löschel et al., 2010b). The surveys revealed that in Germany $63 \%$ of regulated firms had scheduled abatement measures since the EU ETS was introduced in 2005. Larger emitters ( $>$ $25,000 \mathrm{tCO} 2)$ are in general more active in terms of abatement. While $68 \%$ of larger emitters had scheduled abatement measures, $54 \%$ of smaller emitters $(\leq 25,000$ tCO2) did so. By far the most prominent way to realise abatement was process optimisation, accounting for roughly two thirds of scheduled abatement measures (e.g. retrofitting existing machinery or reorganisation of production). Investment in energy efficient technology also played an important role (about $60 \%$ of scheduled measures). Fuels switching or the utilisation of renewable energy as abatement options played a less prominent role in 2009 and 2010. The largest share of realised abatement occurred as a side effect ( $95 \%$ of cases), e.g. as an effect of retrofitting of existing machinery or investment motivated by other reasons than the carbon price. With decreasing free allocation in the EU ETS from 2013 onwards, it is expected that abatement will become more important. 25 $\%$ of surveyed firms in Germany stated that they plan to schedule measures with the primary aim of $\mathrm{CO}_{2}$ abatement from 2013 onwards. The existing installations regulated by the EU ETS have a relative long remaining technical lifetime. Until the year 2026, about nine \% of cumulated emissions will be affected by reinvestment in new machinery. From 2026 until 2031, most installations will likely be replaced, which could heavily affect overall emissions by the utilisations of new and more energy efficient equipment (Löschel et al. 2011).

In 2009 and 2010, about $50 \%$ of firms became active in the carbon market by selling or purchasing allowances. The most important reason for not being active on the market was a sufficient amount of freely allocated permits. Currently, more than $70 \%$ of German companies regulated by the EU ETS receive free allocation that exceeds actual emissions and consequently being over-allocated. This image will change dramatically when free allocation is reduced in 2013. Based on individual expectations of surveyed companies it is estimated that $63 \%$ of companies will receive free allocation that will not cover actual emissions. Although the amount of allowances that must be purchased will be comparably small in many cases, a larger number of firms will have to participate in the market in 2013. In many cases firms might have banked allowances from previous years. Consequently, trading activities might gradually increase, starting in 2013. Most firms traded once per year in 2009 and 2010 (36 \% in 2010). Frequent trades (e.g.) monthly, weekly or daily are conducted almost exclusively by very large emitters. Since allowances are regarded as a commodity, "avoiding speculation" was a frequently named reason for backing away from trading.

In terms of general management issues, most firms (56\% in 2010) organise carbon management by assigning one person as responsible for all relevant tasks. In $29 \%$ of cases, a team is 
responsible for the management. In about $15 \%$ of cases, there are no clearly defined competences. In most cases, where one person is responsible for the management of the EU ETS obligations, an engineer or environmental officer is responsible. Given the current overallocation and moderate trading activities, most firms focus on compliance. In the management of the EU ETS, considerable transaction costs occur. $69 \%$ of transaction costs stem from compliance obligations, such as MRV. Roughly $20 \%$ stem from allowance trading and $11 \%$ from informational costs for abatement technologies (Heindl 2012).

\subsection{Summary of Interviews}

The interviews presented in section 2 reveal that the management structure is clearly dependent on the firm's emissions level and production pattern. Smaller emitters, where installations are located in one place, tend to have one responsible person (probably with a backup person) who organises compliance and trading of allowances (Case 1; 5). Larger emitters with several production sites organise allowance trading centralised while compliance is organised the plant level by responsible engineers (Case 3; 4; 6). Decentralised organisation at larger emitters seems to be a transaction costs minimising strategy. While costs for allowances are charged directly at the installation level in most cases, this does not hold for Case 3. The company is organised in a more centralized manner and allowances are supplied from the center. The frequency of allowance trading is clearly dependent on annual emissions and the amount of free allocation received by firms. Smaller emitters trade less frequent than larger emitters. In Cases 1; 2; 3; and 5, permits are traded with the help of intermediaries, which are mostly banks. Direct permit trading at exchanges is conducted in Case 4; and 6. These firms had trading desks for energy and commodities in place before the EU ETS was introduced and trade a relatively large number of permits. This implies that in Case 4; and 6, synergies in the management can be achieved by integrating permit trading in existing structures and making use of existing knowledge inside the firm. In contrast, firms that have had no trading desk before the introduction of the EU ETS will not implement such organisational structures.

In terms of carbon dioxide abatement, all companies are active, except of Case 3, where no appropriate abatement options exist at the given price level of about EUR 15 or less. The most important abatement options are permanent maintaining of installations and improvements in the production process, which often come along with direct emissions reductions or with a reduction of energy demand in production that reduces emissions indirectly. Direct investment in energy efficient equipment was made in Case 1 and Case 2. In Case 1, a highly efficient trigeneration utility was installed before 2005. The main reason was a German law which promoted combined heat and power (Kraft-Wärme-Kopplungsgesetz). However, the investment was also made in preparation for emissions trading. In Case 2, a highly efficient coal fired plant was built to replace older plants. The EU ETS was an important driver in the investment decision, alongside with rising fuel prices. The remaining firms did not invest in technology that reduces emissions directly. In Case 4, abatement occurred by co-firing biomass materials and partly substituting fossil fuels. In Case 6, abatement decisions are delegated to local installations and are not directly made at the centre. In all cases, the EU ETS currently has a moderate impact on abatement decisions. Low cost abatement options are explored and used consequently. Important reasons for that are rising fuel prices and general increases in efficiency of the production process. With regard to innovation that is directly related to the emissions intensity, it appears that mainly larger 
emitters are active (Case 2; 4; and 6). This is in line with the latest empirical literature (Calel \& Dechezlepretre 2012). It seems important to note that the amount of annual emissions is the most important driver for firm activities in the EU ETS, while other variables like the volume of sales or the number of employees seem to be of less importance. In the cases examined in this paper, innovation occurred in cooperation with external partners. Smaller emitters (Case 1) use the market for the introduction of more efficient equipment. In the cases 2 , and 5 options for buying inputs on the market, such as heat and steam, are considered but not yet realized. This also includes the option to close the EU ETS regulated installations and purchase inputs only on the market (e.g. heat in Case 5).

\section{Conclusion}

Management practices in the EU ETS seem to be highly dependent on pre-existing institutional structures and procedures in regulated firms and their overall emissions and production patterns. For all interviewed firms, compliance with the scheme's obligations was the top priority. MRV comes along with considerable effort and generates costs (Heindl 2012). Carbon dioxide abatement occurred partly as an effect caused by the EU ETS, but also strongly motivated by other aspects, such as savings on inputs fuel and general increases in efficiency in the production process.

While MRV obligations are organised within the firms (with the exemption of external validation of the results), the management of allowances trading often is "outsourced" to intermediaries (banks). In the cases examined in this paper, firms that trade allowances directly at exchanges have existing trading desks for power or commodities and trade a relatively large number of permits. In contrast, no firm introduced a trading desk because of the EU ETS. This highlights the importance of existing structures and management practices with regard to the EU ETS. While the EU ETS generated new management obligations, it did not generate considerable institutional change. This, on the other hand, highlights the importance of intermediaries in the market for EU allowances. Intermediaries seem to be highly important to minimise transaction costs in allowance trading.

It was also observed that innovation with regard to direct emission reductions is carried out by large emitters, while smaller emitters tend to use markets for acquiring energy efficient machinery. The argument here might be closely related to the case of allowance trading. Institutional capacity, available human capital and transaction costs might be a barrier for smaller emitters to engage in "green innovations" that directly reduce emissions from installations regulated by the EU ETS. Also larger emitters tend to carry out innovation processes in cooperation with other commercial partners or universities.

Voluntary efforts of firms to reduce greenhouse gas emissions were observed for all six cases. Those efforts differ strongly and range from simple awareness of the environmental benefits that stem from GHG reductions, to measures such as investment in an eco-friendly car fleet (Case 5), engagement in renewable energy projects (Case 6), and co-firing of biomass (Case 4). Also voluntary environmental management schemes (ISO1400) are regarded as important and beneficial management tool by the firms. In case 4, the firm even defined an internal voluntary 
GHG abatement target. Voluntary environmental efforts offer the possibility to foster positive recognition of the firm and monetary side-benefits, such as cost-savings, i.e. by reduced fuel consumption. Both aspects appeared to be highly important reasons for voluntary environmental efforts. Overall, voluntary efforts have little impact on abatement generated under the EU ETS but positively influence the general environmental performance of the firms.

As a final remark it has to be said that the interviews highlight the difference between the actual practice of emissions trading and the textbook expectations. Especially with regard to the large differences in annual emission volumes in the EU ETS, firms behave differently. While large emitters are perfectly capable to carry out tasks relevant under regulation by quantities (e.g. trading), small emitters behave more passively. This is a direct consequence of the costs for transacting (e.g. trading permits) and the expected return of transactions (i.e. increased allocation and employment of resources within the firm). The institutional response to regulation therefore seems to be an important aspect of the optimal choice and design of regulation, especially in cases where heterogeneous firms in terms of emission volumes and technology are regulated.

\section{References}

André, F.J., González, P. \& Porteiro, N., 2009. Strategic quality competition and the Porter Hypothesis. Journal of Environmental Economics and Management, 57(2), pp.182-194.

Anger, N. \& Oberndorfer, U., 2008. Firm performance and employment in the EU emissions trading scheme: An empirical assessment for Germany. Energy Policy, 36(1), pp.12-22.

Arthur, S. \& Nazroo, J., 2003. Designing Fieldwork Strategies and Materials. In J. Ritchie \& J. Lewis, eds. Case Study Research: Design and Methods. Sage Publications, pp. 109-137.

Bednar-Friedl, B., Schinko, T. \& Steininger, K.W., 2012. The relevance of process emissions for carbon leakage: A comparison of unilateral climate policy options with and without border carbon adjustment. Energy Economics, (forthcoming).

Brockmann, K.L. et al., 2012. KfW/ZEW CO2 Barometer 2012: Anreizwirkung des EU-Emissionshandels auf Unternehmen gering - Klimapolitische Regulierung wenig relevant für Standortentscheidungen, Frankfurt am Main.

Calel, R. \& Dechezlepretre, A., 2012. Environmental Policy and Directed Technological Change: Evidence from the European carbon market. FEEM Working Paper 12-22.

Egenhofer, C., 2007. The Making of the EU Emissions Trading Scheme:Status, Prospects and Implications for Business. European Management Journal, 25(6), pp.453-463.

Ellerman, D.A., Convery, F.J. \& De Pertuis, C., 2010. Pricing Carbon - The European Union Emissions Trading Scheme, Cambridge University Press.

Engels, A., 2009. The European Emissions Trading Scheme: An exploratory study of how companies learn to account for carbon. Accounting, Organizations and Society, 34(3-4), pp.488-498.

Heindl, P., 2012. Transaction Costs and Tradable Permits: Empirical Evidence from the EU Emissions Trading Scheme. ZEW Discussion Paper, 12-021 (Mannheim).

Hoffmann, V., 2007. EU ETS and Investment Decisions: The Case of the German Electricity Industry. European Management Journal, 25(6), pp.464-474. 
Jaraite, J., Convery, F. \& Di Maria, C., 2010. Transaction costs for firms in the EU ETS: Lessons from Ireland. Climate Policy, 10(2), pp.190-215.

Jaraite, J. \& Kazukauskas, A., 2012. Firm Trading Behaviour and Transaction Costs in the European Unions Emission Trading System: An Empirical Assessment. CERE Working Paper, 2012-9 (Umea).

Kautto, N. et al., 2011. Interaction of the EU ETS and national climate policy instruments - Impact on biomass use. Biomass and Bioenergy, 38, pp.117-127.

Löschel, A., Kiehl, K., et al., 2010. KfW/ZEW CO2 Barometer 2010: Effirienapotenziale des Emissionshandels noch nicht ausgeschoepft - Strategien und management deutscher Unternehmen, Frankfurt am Main.

Löschel, A. et al., 2011. KfW/ZEW CO2 Barometer 2011: Hoher Anpassungsbedarf im EU-Emissionshandel ab 2013 deutliche Defizite bei der Vorbereitung in den Unternehmen, Frankfurt am Main.

Löschel, A., Heindl, P., et al., 2010. KfW/ZEW CO2 Panel: Vermeiden oder kaufen - Deutsche Unternehmen im Emissionshandel. Zeitschrift für Energiewirtschaft (ZfE), 34(1), pp.39-46.

Matisoff, D.C., 2010. Making Cap-And-Trade Work: Lessons From The European Union Experience. Environment, (January-February 2010), pp.1-13.

Okereke, C., 2007. An Exploration of Motivations, Drivers and Barriers to Carbon Management: The UK FTSE 100. European Management Journal, 25(6), pp.475-486.

Palmer, K., Oates, W.E. \& Portney, P.R., 1995. Tightening Environmental Standards: The Benefit-Cost or the NoCost Paradigm? Journal of Economic Perspectives, 9(4), pp.119-132.

Porter, M.E. \& Linde, C. van der, 1995. Toward a New Conception of the Environment-Competitiveness Relationship. Journal of Economic Perspectives, 9(4), pp.97-118.

Radgen, P., Butterfield, J. \& Rosenow, J., 2011. EPS, ETS, Renewable obligations and feed in tariffs — Critical reflections on the compatibility of different instruments to combat climate change. Energy Procedia, 4, pp. 5814 5821.

Rogge, K.S., Schneider, M. \& Hoffmann, V.H., 2011. The innovation impact of the EU Emission Trading System: Findings of company case studies in the German power sector. Ecological Economics, 70(3), pp.513-523.

Rubin, I. \& Rubin, H.J., 2004. Qualitative Interviewing, The Art of Hearing Data 2nd Ed., Sage Publications.

Sandoff, A. \& Schaad, G., 2009. Does EU ETS lead to emission reductions through trade? The case of the Swedish emissions trading sector participants. Energy Policy, 37(10), pp.3967-3977.

Solomon, B.D., 1999. New directions in emissions trading: the potential contribution of new institutional economics. Ecological Economics, 30(3), pp.371-387.

Zhang, Y.-J. \& Wei, Y.-M., 2010. An overview of current research on EU ETS: Evidence from its operating mechanism and economic effect. Applied Energy, 87(6), pp.1804-1814. 


\section{Appendix A}

Table 1: Overview and Comparison of Cases

\begin{tabular}{|c|c|c|c|c|c|c|}
\hline Case & 1 & 2 & 3 & 4 & 5 & 6 \\
\hline $\begin{array}{l}\text { Allocation tCO2 } \\
\text { (p.a. Phase II) }\end{array}$ & 140,000 & $6,000,000$ & 900,000 & $\mathrm{NA} *$ & 5,700 & $2,500,000$ \\
\hline $\begin{array}{l}\text { Emissions tCO2 } \\
\text { (p.a. average) }\end{array}$ & 70,000 & $7,000,000$ & 750,000 & $20,000,000$ & 6,700 & $4,000,000$ \\
\hline $\begin{array}{l}\text { Number of } \\
\text { installations }\end{array}$ & 1 & 5 & 22 & 43 & 1 & several \\
\hline Position & Long & Short & Long & Long & Short & Short \\
\hline Trading & $\begin{array}{l}6 \text { times p.a. } \\
\text { via bank(s) }\end{array}$ & $\begin{array}{l}\text { No: Permits } \\
\text { delivered by holding } \\
\text { companies }\end{array}$ & $\begin{array}{l}20 \text { times p.a. } \\
\text { via bank(s) }\end{array}$ & $\begin{array}{l}\text { Up to daily, } \\
\text { own trading desk }\end{array}$ & $\mathrm{No}$ & $\begin{array}{l}\text { Up to daily, } \\
\text { own trading desk }\end{array}$ \\
\hline Trading strategy & Selling & - & Banking & Selling & $\begin{array}{l}\text { Borrowing from next } \\
\text { year's free allocation }\end{array}$ & Hedging \\
\hline Abatement & $\begin{array}{l}\text { Yes (before 2005) } \\
\text { energy efficiency }\end{array}$ & $\begin{array}{l}\text { Yes } \\
\text { energy efficiency }\end{array}$ & No & $\begin{array}{l}\text { Yes } \\
\text { fuel switch }\end{array}$ & $\mathrm{No}$ & $\begin{array}{l}\text { Decisions made at } \\
\text { local installations }\end{array}$ \\
\hline Innovation & $\mathrm{No}$ & Yes & $\mathrm{No}$ & Yes & No & Yes \\
\hline Employees & 33,000 & 600 & 17,700 & 55,000 & 15,000 & 6,000 \\
\hline $\begin{array}{l}\text { Volume of Sales } \\
\text { (million EUR) }\end{array}$ & 5,000 & 450 & 6,200 & 11,000 & 2,600 & 3,400 \\
\hline Branch & $\begin{array}{l}\text { Various industrial } \\
\text { products }\end{array}$ & Power generation & Food industry & $\begin{array}{l}\text { Production of inputs for } \\
\text { the construction sector }\end{array}$ & Production of machinery & Energy supply \\
\hline Market Activities of firm & Global & National & Europe & Global & Global & Europe \\
\hline Technology & $\begin{array}{l}\text { Combustion installation } \\
\text { (trigeneration) for local } \\
\text { energy supply }\end{array}$ & $\begin{array}{l}\text { Coal fired power plant for } \\
\text { power generation and } \\
\text { district heating }\end{array}$ & $\begin{array}{l}\text { Combustion installations } \\
\text { and lime }\end{array}$ & $\begin{array}{l}\text { Combustion installations } \\
\text { and process emissions }\end{array}$ & $\begin{array}{l}\text { Combustion installation } \\
\text { for heat generation }\end{array}$ & $\begin{array}{l}\text { Several combustion } \\
\text { installations }\end{array}$ \\
\hline $\begin{array}{l}\text { Market where good } \\
\text { produced by EU ETS } \\
\text { facilities is sold }\end{array}$ & National & National & Europe & Global & National & Europe \\
\hline Carbon Leakage List & No & No & Yes & Yes & No & No \\
\hline
\end{tabular}

* NA: information not available 


\section{Appendix B: Outline of Questions (Interview Guidelines)}

\section{Introductory Questions on Company, Plants, Technology, and Responsibilities:}

\section{Questions concerning the Company and Plants}

a) Number of employees

b) Revenue of the company (magnitude)

c) Number of competitors / optionally naming them / location of the competitors?

- It is possible to concentrate on a company branch or a product (e.g. best-selling)

d) Asset investments of the company (also outside Germany, emissions)

e) Plant structure / classification in the company

- Functions of the plants (central role in production)?

f) How complex is (are) the plant(s)? Which abatement options exist theoretically?

\section{Questions concerning Interview Partner}

a) Position of the interviewee in the company

b) Technical or rather commercial background

\section{Questions on Abatement}

1. Relevance of $\mathrm{CO}_{2}$ costs as part of (replacement) investment decisions compared to wage/production costs, technical factors, financial calculation, etc.

2. Have any $\mathrm{CO}_{2}$ abatement measures been taken so far (which ones?, how exactly did this happen?)

a. If so: Investment volume / yielded savings (amount of $\mathrm{CO}_{2} /$ percentage respectively operating costs)

3. Have $\mathrm{CO}_{2}$ abatement options/costs been evaluated systematically so far? (deliberately yes/no, no subordinated)

4. What mitigation potentials are seen overall? (price: 20EUR / 30EUR)

5. Structure of mitigation costs (function) e.g.: high fix costs, delayed pay-offs etc.

6. How "complex" would $\mathrm{CO}_{2}$ abatement be?

7. Barriers for $\mathrm{CO}_{2}$ abatement (institutionally/technologically/financially)

8. Are there any markets for abatement technology?

9. How extensive is the search for abatement options?

10. Possibility of carbon leakage?

a. Is a relocation currently being planned?

b. Relocation already taken place?

c. What impact do $\mathrm{CO}_{2}$ prices have in this decision process compared to wage/material costs, infrastructure, energy costs, other taxes/requirements/duties - threshold price of $\mathrm{CO}_{2}$ when $\mathrm{CO}_{2}$ costs are taken into consideration.

11. Possibility of outsourcings? (elimination of plants and purchase of e.g. energy)

\section{Questions on Trade}

1. How often does your company enter the market for trade? (Number of trades per trading year?)

a. Participation on the market over the time period - today greater than during phase I and beginning of phase II. 
2. How does the allocation influence the trading decision? Can you explain the motivation and/or the trading strategy to us? - For instance, do you only trade if you have a certain surplus of certificate?

a. How do you decide on the number of certificates that will be bought/sold or traded?

i. What is your decision based on? E.g., prognoses, prices/energy consumptions

ii. Are the trade revenue and emission reduction costs being counterbalanced?

3. What is being traded?/Which certificates or credits does your company trade? (EEAs/CERs/ERUs)

4. Are derivatives being traded?

a. If so: are there any internal regulations in the company or group? (Solely hedge of existing positions or unlimited trade)

5. Does the company engage in the market itself or does your company enter the market via an intermediary? (company, intermediary)

6. Several plants: trade carried out internally?

7. What role does fraud play (phishing/value added tax fraud) for the perception of trade? (Trust in regulation measure)

8. Does the company create internal price forecasts/evaluations of the market situation?

9. How high is the estimated level of information?

\section{Questions on Carbon Management}

1. How is the management of emissions trading arranged in general?

a. (Where is trade/compliance situated?)

2. In general: Is climate change part of the company objectives? Which role does corporate social responsibility play? Is there something like a $\mathrm{CO}_{2}$ reduction objective on the company level?

a. (Where is strategy situated in general?)

3. Is there a team of technical and commercial employees?

4. How should the management be organised ideally?

5. Are there any incentives for employees to locate abatement potentials (e.g. suggestion scheme, voluntary calls for more environmental awareness)

6. How high are the estimated transaction costs?

7. Which external services are used?

8. What is done by the company itself?

9. Is there an environmental management system (EMS) / certified EMS?

\section{Questions on Uncertainty}

1. Which impacts does the price volatility have on

a. The trading strategy (on a short term basis)

b. Abatement/ investment/ innovation (on a long term basis)

2. Which impacts does regulatory uncertainty concerning climate and energy policy have? (EU/Ger - e.g. Energy Efficiency Directive etc.)

a. Impacts on trading strategy (on a short term basis)

b. Impacts on abatement/ investment / innovation (on a long term basis)

3. Does the uncertainty affect the preferences with regard to the "optimal" regulation? (Prices vs. quantity vs. command and control approaches)

4. What are your expectations for the third trading period 2013 - 2020? (Allocation, impacts on companies, price development) 
5. Will the strategy change in the third trading period of the EU ETS? If so, how?

\section{Questions on Innovation}

1. Does the company innovate? Is research and development carried out by the company itself? (Regarding innovations in the field of emissions reduction)

a. Separation of process and product innovation (development of new products to help clients reduce $\mathrm{CO}_{2}$ emissions)

b. If not: How are mitigation technologies being procured?

2. Does the search for "new" technology result in additional costs?

3. How is the decision for/against the adaption of new technologies being made?

4. Structure, process, introduction of new technologies 